\title{
Pengaruh Pupuk Anorganik dan Organik terhadap Pertumbuhan, Produksi dan Kualitas Umbi serta Ketahanan terhadap Hama pada Bawang Merah
}

\author{
The Effect of Inorganic and Organic Fertilizers on the Growth, Production \\ and Quality of Tubers, and Pest Resistance of Shallots
}

\author{
Arief Fidiansyah $^{1}$, Sudirman Yahya ${ }^{2 *}$, dan Suwarto ${ }^{2}$ \\ ${ }^{1}$ Program Studi Agronomi dan Hortikultura, Sekolah Pascasarjana, Institut Pertanian Bogor \\ ${ }^{2}$ Departemen Agronomi dan Hortikultura, Fakultas Pertanian, Institut Pertanian Bogor \\ (IPB University), Jl. Meranti, Kampus IPB Darmaga, Bogor 16680, Indonesia
}

Diterima 16 Desember 2020/Disetujui 14 April 2021

\begin{abstract}
The high use of inorganic fertilizers in the long term for fertilizing shallots along with the high cost of inorganic fertilization could resulting in a decrease in the quality of shallots. The research was carried out to study the effect of goat manure application along with a dose of inorganic fertilizers on the growth, production, and quality of shallots, as well as resistance to pests. The research was conducted during the dry season from September to December 2019 in Sukorejo Village, Nganjuk with temperature conditions of $23-33^{\circ} \mathrm{C}$ and an altitude of 60 to 140 masl. The field experiment used a nested design of four replications with two factors, where the first factor was two levels of manure of organic fertilizer, and the second factor was five levels of inorganic fertilizer. The inorganic fertilizers used were urea, $\mathrm{KCl}$, and NPK. The reference dosage for inorganic fertilizers uses the local farmer's dose. Manure did not work to reduce the dose of inorganic fertilizers on shallot growth. The application of manure significantly reduced plant height by $36.88 \mathrm{~cm}$, lower than without manure at $39.03 \mathrm{~cm}$ but increased the number of leaves, number of tillers, and tuber weight per clump. The addition of goat manure organic fertilizer causes the proportion of shallot damage to $1.40 \%$ on the tubers 6 weeks after storage (MSS) but it is still below 5\% according to the quality requirements of shallots SNI 01-3159-1992.
\end{abstract}

Keywords: tuber weight, goat manure, manure, Super Phillip

\section{ABSTRAK}

Penggunaan pupuk anorganik yang tinggi dalam jangka panjang pada pemupukan bawang merah disertai tingginya biaya pemupukan anorganik dapat mengakibatkan penurunan kualitas bawang merah. Penelitian dilaksanakan bertujuan untuk mempelajari pengaruh penggunaan pupuk kotoran kambing dengan dosis pupuk anorganik terhadap pertumbuhan, produksi, dan kualitas bawang merah, serta ketahanan terhadap hama. Penelitian dilaksanakan pada musim kemarau di bulan September hingga Desember 2019 di Desa Sukorejo, Nganjuk dengan kondisi suhu 23-33 ${ }^{\circ} \mathrm{C}$ dan ketinggian 60 sampai $140 \mathrm{mdpl}$. Penelitian ini menggunakan rancangan petak tersarang (nested design), empat ulangan dengan dua faktor. Faktor pertama yaitu pupuk kandang yang terdiri atas dua taraf, dan faktor kedua yaitu pupuk anorganik yang terdiri atas lima taraf. Pupuk anorganik yang digunakan yaitu urea, $\mathrm{KCl}$, dan NPK. Dosis acuan pupuk anorganik menggunakan dosis petani setempat. Pupuk kandang tidak berhasil mengurangi dosis pupuk anorganik pada pertumbuhan bawang merah. Pemberian pupuk kandang secara nyata menurunkan tinggi tanaman $36.88 \mathrm{~cm}$ lebih rendah dari tanpa pupuk kandang $39.03 \mathrm{~cm}$ tetapi meningkatkan jumlah daun, jumlah anakan dan bobot umbi per rumpun. Penambahan pupuk organik kotoran kambing menyebabkan persentase kerusakan bawang merah $1.40 \%$ pada umbi 6 minggu setelah simpan (MSS) tetapi masih di bawah 5\% sesuai syarat mutu SNI 01-3159-1992 bawang merah.

Kata kunci: bobot umbi, kotoran kambing, pupuk kandang, Super Philip

\footnotetext{
*Penulis untuk korespondensi. e-mail: syahya49@yahoo.co.id
} 


\section{PENDAHULUAN}

Bahan organik memiliki peran penting dilihat dari dua aspek yaitu aspek tanah dan tanaman. Dari aspek tanah, pelapukan bahan organik dapat membantu memberikan unsur hara N, P, K dalam tanah yang dibutuhkan tanaman, memperbaiki struktur tanah aerasi tanah dan memperbaiki sifat fisik tanah. Selanjutnya dari aspek tanaman, hasil pelapukan bahan organik mengandung asam organik yang dapat meningkatkan ketersediaan unsur hara tanaman dan dapat diserap langsung oleh tanaman Elisabeth et al., 2013).

Bobot basah, bobot kering, diameter umbi, dan produksi umbi bawang merah lebih tinggi pada plot yang diberi perlakuan pupuk kandang. Pertumbuhan vegetatif bawang merah yang tinggi pada perlakuan pupuk kandang menyebabkan intersepsi radiasi fotosintesis aktif lebih optimal, yang kemudian akumulasi asimilatnya yang tinggi akan disimpan di umbi (Bua et al., 2017). Pupuk organik mempunyai pengaruh positif terhadap pertumbuhan dan produksi bawang. Oleh karena itu kelompok tani harus didorong agar menggunakan pupuk organik dalam budidaya bawang merah untuk menggantikan pupuk anorganik yang mahal dan juga mempunyai efek negatif (Bua et al., 2017). Penggunaan pupuk kandang dalam konsep pertanian berkelanjutan mampu mencegah serangan hama penyakit dengan meningkatnya kandungan saponin dalam umbi bawang merah. Oleh karena itu diperlukan kajian tentang pengaruh kombinasi pupuk kandang kotoran kambing dan pupuk anorganik terhadap pertumbuhan, produksi, kualitas umbi, serta ketahanan terhadap hama pada tanaman bawang merah.

\section{BAHAN DAN METODE}

Pupuk anorganik yang digunakan yaitu urea, $\mathrm{KCl}$, dan NPK. Dosis acuan pupuk anorganik menggunakan dosis petani setempat. Dosis acuan urea $167 \mathrm{~kg} \mathrm{ha}^{-1}(75.15 \mathrm{~kg} \mathrm{~N}$ $\mathrm{ha}^{-1}$ ), NPK $167 \mathrm{~kg} \mathrm{ha}^{-1}\left(25.05 \mathrm{~kg} \mathrm{~N} \mathrm{ha}^{-1} ; 25.05 \mathrm{~kg} \mathrm{P}_{2} \mathrm{O}_{5} \mathrm{ha}^{-1}\right.$; $25.05 \mathrm{~kg} \mathrm{~K}_{2} \mathrm{O} \mathrm{ha}^{-1}$ ) dan $\mathrm{KCl} 167 \mathrm{~kg} \mathrm{ha}^{-1}\left(100.2 \mathrm{~kg} \mathrm{~K}_{2} \mathrm{O}\right.$ $\left.\mathrm{ha}^{-1}\right)$. Pupuk organik yang digunakan berasal dari kotoran kambing dengan dosis 0 dan 10 ton ha ${ }^{-1}$.

Penelitian berupa percobaan lapangan menggunakan metode rancangan petak tersarang (Nested design), empat ulangan dengan dua faktor, yaitu faktor pertama: pupuk kandang yang terdiri dari dua taraf dan faktor kedua pupuk anorganik terdiri dari lima taraf. Model linier aditif dari rancangan petak tersarang (Nested design) tersebut adalah: $\mathrm{Y}_{\mathrm{ijk}}=\mu+\alpha_{\mathrm{i}}+\delta \mathrm{k}_{(\mathrm{i})}+\beta_{\mathrm{j}}+\alpha_{\beta_{\mathrm{ij}}}+€_{\mathrm{ijk}}$.

Penelitian dilaksanakan di Desa Sukorejo, Kabupaten Nganjuk suhu rata-rata di lokasi penelitian sekitar $23-33{ }^{\circ} \mathrm{C}$ dan dengan ketinggian sekitar 60 sampai 140 mdpl. Percobaan dilakukan pada lahan yang sering digunakan petani dengan pola tanam padi-kedelai-bawang merah-bawang merah. Percobaan dilakukan pada bulan September 2019 sampai Desember 2019. Analisis hara tanah dan tanaman dilaksanakan di Laboratorium Pengujian Departemen Agronomi dan Hortikultura IPB.

Peubah dalam penelitian ini meliputi pertumbuhan bawang merah (tinggi tanaman, total daun dan total anakan), produksi (total umbi per rumpun, bobot umbi per rumpun, bobot umbi per 100 rumpun dan produktivitas ton $\mathrm{ha}^{-1}$ ), kualitas (tingkat kekerasan umbi, persentase bobot umbi per rumpun, persentase diameter umbi per rumpun, karakter bentuk umbi, susut bobot dan kerusakan) dan tingkat kejadian dan serangan hama (dihitung menggunakan acuan rumus IS $=\frac{\sum n i \times v i}{N \times v} \times 100 \%$ ). Data pengamatan yang diperoleh dianalisis dengan menggunakan analisis ragam (uji F). Apabila uji $\mathrm{F}$ nyata maka dilanjutkan uji lanjut ortogonal polynomial untuk menentukan bentuk respon dengan peubah terhadap dosis pupuk anorganik.

\section{HASIL DAN PEMBAHASAN}

\section{Pertumbuhan dan Produksi}

Interaksi dosis pupuk anorganik dan pupuk kotoran kambing tidak memberikan pengaruh nyata terhadap pertumbuhan tinggi tanaman, total anakan dan total daun. Secara tunggal pupuk anorganik (Urea, KCl, NPK) berpengaruh nyata terhadap pertumbuhan tinggi tanaman. Penggunaan pupuk kotoran kambing menunjukkan pengaruh nyata terhadap tinggi tanaman pada $3 \mathrm{MST}$, $4 \mathrm{MST}$, $5 \mathrm{MST}$ dan 6 MST. Tabel 1 menunjukkan bahwa pemberian pupuk kotoran kambing secara nyata menekan tinggi tanaman diduga hal ini terjadi karena kandungan $\mathrm{N}$-total tanah pada semua perlakuan setelah perlakuan termasuk pada kategori rendah berkisar $0.10-0.14 \%$ sehingga tidak memberikan pengaruh yang nyata pada pertumbuhan. Messele (2016) menyatakan, kekurangan $\mathrm{N}$ membatasi pembelahan dan ekspansi sel, perkembangan kloroplas, konsentrasi klorofil, dan aktivitas enzim. Kebutuhan bawang merah terhadap $\mathrm{N}$ cukup tinggi yaitu $64.26 \mathrm{~kg} \mathrm{~N} \mathrm{ha}^{-1}$ (Sumarni et al., 2017), namun kandungan hara $\mathrm{N}$ pada tanah rendah sehingga mengurangi serapan $\mathrm{N}$ oleh tanaman. Penambahan pupuk kotoran kambing tidak meningkatkan kandungan C-organik tanah rata-ratanya $0.67 \%$ dari kandungan sebelumnya $0.98 \%$ sehingga terjadi penurunan sekitar $0.32 \%$ C-Organik.

Penambahan 10 ton ha $^{-1}$ POKK nyata meningkatkan jumlah daun dari 2 MST hingga 6 MST (Tabel 2). Bertambahnya jumlah daun hingga 5 MST yaitu 35 helai/ rumpun. Hal ini diduga aplikasi pupuk organik dapat meningkatkan kadar hara, terutama N sehingga jumlah daun lebih banyak dengan pemupukan organik. Jumlah anakan atau umbi per rumpun lebih disebabkan oleh pertumbuhan tanaman dan interaksinya dengan kondisi lingkungan (Tabel 3) perlakuan pupuk 10 ton ha-1 $\mathrm{POKK}$ nyata pada $2 \mathrm{MST}, 4$ MST dan 6 MST meningkatkan jumlah anakan per rumpun berturut-turut mencapai sejumlah rata-rata 4.27, 5.12, dan 7.57. Dari ketiga peubah menunjukkan bahwa POKK nyata menekan tinggi tanaman tetapi nyata berhasil meningkatkan jumlah daun dan jumlah anakan diduga pemberian pupuk anorganik tidak mampu diserap oleh bawang merah secara optimal terutama unsur hara nitrogen namun dengan POKK ternyata cukup mampu mencapai standar kualitas bawang merah super philip yang ditentukan pada Surat Keputusan Kementerian Pertanian RI Nomor 66/KPTS/TP.240/2 tahun 2000 yaitu tinggi tanaman 36-45 cm dan jumlah daun 22-29 helai per rumpun. 
Tabel 1. Pengaruh pupuk kotoran kambing dan dosis anorganik terhadap pertumbuhan bawang merah

\begin{tabular}{llccc}
\hline \multirow{2}{*}{ Perlakuan } & \multicolumn{3}{c}{ Umur tanaman } \\
\cline { 2 - 5 } & 3 MST & 4 MST & MST & \\
Organik & \multicolumn{2}{c}{ Tinggi tanaman (cm) } \\
P0 & $31.4 \mathrm{a}$ & $36.5 \mathrm{a}$ & $38.4 \mathrm{a}$ & $39.0 \mathrm{a}$ \\
P1 & $34.6 \mathrm{~b}$ & $37.6 \mathrm{~b}$ & $36.8 \mathrm{~b}$ \\
Anorganik & $28.8 \mathrm{~b}$ & & & 39.4 \\
A0 & 30.8 & 36.6 & 39.3 & 38.1 \\
A1 & 30.0 & 35.1 & 38.3 & 37.6 \\
A2 & 29.8 & 34.9 & 37.5 & 37.1 \\
A3 & 29.4 & 35.2 & 37.0 & 37.5 \\
A4 & 30.4 & 36.0 & 38.0 & $0.02 * \mathrm{~L}$ \\
\hline Uji polynomial & & & \\
\hline
\end{tabular}

Keterangan: Angka yang diikuti oleh huruf yang sama pada kolom yang sama tidak berbeda nyata. $\mathrm{P} 0=0$ ton ha ${ }^{-1} ; \mathrm{P} 1=10$ ton ha ${ }^{-1} ; \mathrm{A} 0=$ $0 \%$ dosis acuan; $\mathrm{A} 1=25 \%$ dosis acuan; $\mathrm{A} 2=50 \%$ dosis acuan; $\mathrm{A} 3=75 \%$ dosis acuan; $\mathrm{A} 4=100 \%$ dosis acuan. $*=$ nyata; $* *$ = sangat nyata; $\mathrm{L}=$ Linear; $\mathrm{K}=$ Kuadratik; MST = minggu setelah tanam

Dosis pupuk lebih banyak justeru tidak mengalami peningkatan tinggi tanaman, menurut Abdissa et al. (2011) hara $\mathrm{N}$ terlibat langsung dalam pembentukan asam amino, protein, asam nukleat, enzim, nukleoprotein dan alkaloid yang sangat dibutuhkan untuk proses pertumbuhan tanaman, terutama perkembangan daun, serta pembentukan anakan. Sumarni et al. (2012) juga menyatakan, pemupukan N, P, dan $\mathrm{K}$ meningkatkan tinggi tanaman dan bobot tanaman. Perbedaan dengan penelitian sebelumnya adalah baik dengan atau tanpa POKK (Tabel 1 dan Gambar 1A) tinggi tanaman menunjukkan penurunan secara linear terhadap peningkatan dosis pupuk anorganik (NPK 15:15:15, Urea, KCl) dengan persamaan $\left(\mathrm{y}=-0.0192 \mathrm{x}+38.916\left(\mathrm{R}^{2}=0.7427\right)\right.$, hal ini ditunjukan pada analisis tanah setelah panen rata-rata $\mathrm{N}$ total $0.12 \%$ hampir sama pada tiap perlakuan sedangkan $\mathrm{P}$ tersedia dan $\mathrm{K}$ total termasuk kategori tinggi yaitu 112.33 $\mathrm{P}_{2} \mathrm{O}_{5}$ ppm dan $88.38 \mathrm{mg} \mathrm{K}_{2} \mathrm{O} 100 \mathrm{~g}^{-1}$.
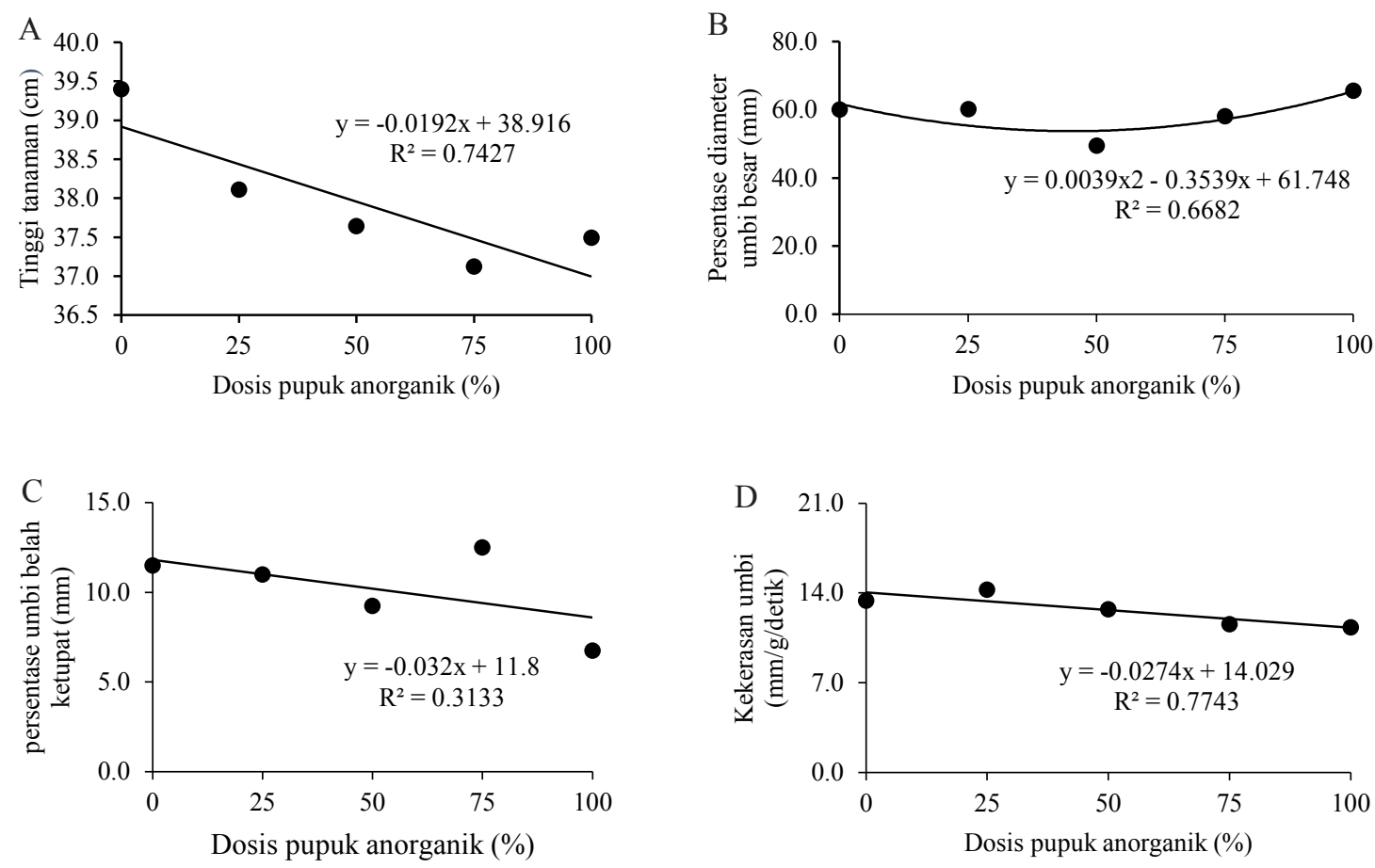

Gambar 1. Kurva perlakuan terhadap bawang merah: A) pengaruh pupuk anorganik tinggi tanaman 6 MST; B) pengaruh pupuk anorganik terhadap diameter umbi besar; C) Respon umbi belah ketupat terhadap taraf pupuk anorganik pada pemberian 10 ton ha ${ }^{-1}$; D) Pengaruh pupuk anorganik terhadap kekerasan umbi 
Tabel 2. Pengaruh pupuk kotoran kambing terhadap total daun bawang merah

\begin{tabular}{|c|c|c|c|c|c|}
\hline \multirow{2}{*}{ Perlakuan } & \multicolumn{5}{|c|}{ Umur tanaman } \\
\hline & $2 \mathrm{MST}$ & $3 \mathrm{MST}$ & $4 \mathrm{MST}$ & $5 \mathrm{MST}$ & $6 \mathrm{MST}$ \\
\hline & \multicolumn{5}{|c|}{ Total daun (helai) } \\
\hline \multicolumn{6}{|l|}{ Organik } \\
\hline $\mathrm{P} 0$ & $13.5 b$ & $25.8 b$ & $29.9 b$ & $30.3 b$ & $28.1 b$ \\
\hline $\mathrm{P} 1$ & $18.2 \mathrm{a}$ & $28.2 \mathrm{a}$ & $33.1 \mathrm{a}$ & $35.0 \mathrm{a}$ & $33.4 \mathrm{a}$ \\
\hline
\end{tabular}

Keterangan: Angka yang diikuti oleh huruf yang sama pada kolom yang sama tidak berbeda nyata. $\mathrm{P} 0=0$ ton ha ${ }^{-1} ; \mathrm{P} 1=10$ ton ha ${ }^{-1}$; MST $=$ minggu setelah tanam

Tabel 3. Pengaruh pupuk kotoran kambing terhadap total anakan bawang merah

\begin{tabular}{lccc}
\hline \multirow{2}{*}{ Perlakuan } & \multicolumn{3}{c}{ Umur tanaman } \\
\cline { 2 - 5 } & $2 \mathrm{MST}$ & $4 \mathrm{MST}$ & $6 \mathrm{MST}$ \\
\hline & & Total anakan & \\
Organik & & & $7.1 \mathrm{~b}$ \\
P0 & $3.9 \mathrm{~b}$ & $4.7 \mathrm{~b}$ & $7.6 \mathrm{a}$ \\
P1 & $4.3 \mathrm{a}$ & $5.1 \mathrm{a}$ & \\
\hline
\end{tabular}

Keterangan: Angka yang diikuti oleh huruf yang sama pada kolom yang sama tidak berbeda nyata. $\mathrm{P} 0=0$ ton ha ${ }^{-1} ; \mathrm{P} 1=10$ ton ha ${ }^{-1} ; \mathrm{MST}^{-}$ $=$ minggu setelah tanam

Aplikasi pupuk kotoran kambing salah satu komponen hasil rata-rata yang nyata lebih tinggi dibandingkan tanpa pupuk kotoran kambing. Rata-rata bobot umbi per 100 rumpun yang tidak menggunakan pupuk kotoran kambing yaitu $5.6 \mathrm{~kg}$. Sementara dengan 10 ton ha ${ }^{-1}$ pupuk kotoran kambing menghasilkan rata-rata bobot $6.2 \mathrm{~kg}$ umbi per 100 rumpun (Tabel 4). Ramli et al. (2016) menyatakan, bobot isi tanah (bulk density) dipengaruhi kandungan bahan organik dan tingkat kepadatan tanah, dimana bahan organik yang semakin tinggi menyebabkan bobot isi tanah akan semakin rendah yang berarti struktur tanah menjadi lebih gembur. Tekstur tanah yang gembur menyebabkan penetrasi, pertumbuhan, dan pemanjangan akar lebih mudah. Akar yang panjang pada bawang merah akan meningkatkan serapan hara sehingga akan meningkatkan produktivitas bawang merah. Pemberian pupuk kotoran kambing 10 ton $\mathrm{ha}^{-1}$ berhasil nyata meningkatkan besaran produksi (32.8\%)

Tabel 4. Pengaruh pupuk kotoran kambing terhadap berat umbi per 100 rumpun bawang merah

\begin{tabular}{ccc}
\hline Perlakuan & $\begin{array}{c}\text { Rata-rata bobot } \\
\text { umbi per } 100 \\
\text { rumpun }(\mathrm{kg})\end{array}$ & $\begin{array}{c}\text { Rata-rata produktivitas } \\
\text { berdasarkan umbi per } \\
100 \text { rumpun }\left(\text { ton } \mathrm{ha}^{-1}\right)\end{array}$ \\
\hline Organik & & \\
P0 & $5.6 \mathrm{~b}$ & $22.2 \mathrm{~b}$ \\
P1 & $6.2 \mathrm{a}$ & $24.6 \mathrm{a}$ \\
\hline
\end{tabular}

Keterangan: Angka yang diikuti oleh huruf yang sama pada kolom yang sama tidak berbeda nyata. $\mathrm{P} 0=0$ ton ha ${ }^{-1} ; \mathrm{P} 1=$ 10 ton $\mathrm{ha}^{-1} ; \mathrm{MST}=$ minggu setelah tanam dari bobot umbi per 100 rumpun dari $5.6 \mathrm{~kg}$ menjadi $6.2 \mathrm{~kg}$ umbi per 100 rumpun atau 24.6 ton ha ${ }^{-1}$. Produksi tersebut sudah melebihi standar yang ditetapkan pada Varietas Super Philip Keputusan Menteri Pertanian Nomor 66/KPTS/ TP.240/2 tahun 2,000 yaitu 17.6 ton $\mathrm{ha}^{-1}$.

\section{Mutu Umbi}

Pemupukan anorganik (Urea, NPK 15:15:15, KCl) memberikan pengaruh pada kekerasan umbi dan persentase diameter umbi besar dan pemupukan organik memberikan pengaruh nyata pada peubah kekerasan umbi dan persentase kerusakan umbi di 6 MSP. Interaksi pupuk anorganik (Urea, NPK 15:15:15, KCl) dan pupuk kotoran kambing memberikan pengaruh nyata pada persentase persentase umbi belah ketupat. Pemberian pupuk kotoran kambing tidak mempengaruhi secara nyata pada persentase diameter bawang merah. Persentase diameter umbi besar bawang merah menunjukkan respon kuadratik dengan persamaan y $=0.0039 \mathrm{x}^{2}-0.3539 \mathrm{x}+61.748$ terhadap peningkatan dosis pupuk anorganik (Tabel 5 dan Gambar 1B). Hal ini apabila dikaitkan pada Gambar 1A kurva pertumbuhan bawang merah pada 6 MST menunjukkan bahwa penggunaan pupuk anorganik $0 \%$ lebih efisien daripada pemupukan pupuk anorganik 100\% sehingga apabila tidak diberi pupuk tanaman bawang merah dapat berkualitas dengan baik. Sebagaimana ditampilkan pada Tabel 5, pemberian pupuk anorganik tidak berhasil meningkatkan produksi, sebaliknya menurunkan kualitas produksi bawang merah seperti pada persentase diameter umbi besar (Gambar 1B) dan kekerasan umbi (Gambar 1D). 
Fidiansyah et al. / J. Agron. Indonesia 49(1):53-59

Tabel 5. Pengaruh pupuk anorganik terhadap persentase diameter umbi besar bawang merah

\begin{tabular}{lccc}
\hline Dosis pupuk anorganik & $\begin{array}{c}\text { Tanpa pupuk organik } \\
\text { P0 (\%) }\end{array}$ & $\begin{array}{c}\text { Pupuk organik } \\
\text { P1 (\%) }\end{array}$ & $\begin{array}{c}\text { Rata-rata } \\
\text { P0+P1 }\end{array}$ \\
\hline A0 & 64.6 & 55.5 & 60.1 \\
A1 & 48.9 & 71.3 & 60.1 \\
A2 & 49.4 & 49.6 & 49.5 \\
A3 & 66.4 & 49.8 & 58.1 \\
A4 & 67.8 & 63.4 & 65.7 \\
\hline Rata-rata (Uji polynomial) & 59.4 & 57.9 & $58.7(0.03 * \mathrm{~K})$ \\
\hline
\end{tabular}

Keterangan: $\mathrm{P} 0=0$ ton $\mathrm{ha}^{-1} ; \mathrm{P} 1=10$ ton $\mathrm{ha}^{-1} ; \mathrm{A} 0=0 \%$ dosis acuan; $\mathrm{A} 1=25 \%$ dosis acuan; $\mathrm{A} 2=50 \%$ dosis acuan; $\mathrm{A} 3=75 \%$ dosis acuan; A4 = 100\% dosis acuan; Uji orthogonal polynomial; *= pengaruh nyata; ** = pengaruh sangat nyata; $\mathrm{L}=$ linear; $\mathrm{K}=$ kuadratik

Perlakuan tanpa pupuk kotoran kambing (Tabel 6) pemberian pupuk anorganik tidak berpengaruh nyata, namun apabila dikombinasikan dengan pemberian pupuk kotoran kambing, peningkatan dosis pupuk anorganik menurunkan mutu dengan nyata persentase umbi belah ketupat (Gambar 1C) secara linear dengan persamaan $y=-0.032 x+11.8$. Pemberian pupuk kotoran kambing pada bawang merah memberikan pengaruh pada penurunan kekerasan umbi. Tabel 7 dan Gambar 1D menunjukkan bahwa tingkat kekerasan umbi varietas Super Philip menurun secara linear terhadap peningkatan dosis pupuk anorganik dengan persamaan $\mathrm{y}=-0.0274 \mathrm{x}+14.029$. Pemberian pupuk anorganik tidak berhasil meningkatkan produksi, sebaliknya menurunkan kualitas produksi, penggunaan pupuk anorganik berpengaruh pada kualitas bawang merah seperti kekerasan umbi. Bawang merah termasuk produk hortikultura jenis non klimaterik sehingga produksi etilennya sangat rendah. Produksi etilen dapat meningkatkan laju respirasi sehingga terjadi proses pelunakan pada jaringan umbi bawang merah, diduga pemupukan anorganik lebih rendah memiliki etilen lebih tinggi dari perlakuan lain sehingga jaringan

Tabel 6. Pengaruh interaksi terhadap persentase bentuk umbi belah ketupat bawang merah

\begin{tabular}{lcc}
\hline $\begin{array}{l}\text { Dosis pupuk } \\
\text { anorganik }\end{array}$ & $\begin{array}{c}\text { Tanpa pupuk organik } \\
\text { P0 }(\%)\end{array}$ & $\begin{array}{c}\text { Pupuk organik } \\
\text { P1 }(\%)\end{array}$ \\
\hline A0 & 6.5 & 11.5 \\
A1 & 10.2 & 11 \\
A2 & 12.2 & 9.2 \\
A3 & 7 & 12.5 \\
A4 & 11.5 & 6.7 \\
\hline Rata-rata (Uji & $9.5(0.68 \mathrm{tn})$ & $10.2\left(0.006^{* *} \mathrm{~L}\right)$ \\
polynomial $)$ & & \\
\hline
\end{tabular}

Keterangan: $\mathrm{P} 0=0$ ton $\mathrm{ha}^{-1} ; \mathrm{P} 1=10$ ton $\mathrm{ha}^{-1} ; \mathrm{A} 0=0 \%$ dosis acuan; $\mathrm{A} 1=25 \%$ dosis acuan; $\mathrm{A} 2=50 \%$ dosis acuan; $\mathrm{A} 3$ $=75 \%$ dosis acuan; A4 $=100 \%$ dosis acuan; Uji orthogonal polynomial: $*=$ pengaruh nyata; $* *=$ pengaruh sangat nyata; $\mathrm{L}=$ linear; $\mathrm{K}=$ kuadratik umbi bawang merah lebih lunak. Downes et al. (2010) menyebutkan bahwa produksi etilen berpengaruh terhadap laju respirasi dan perkecambahan pada bawang bombai.

Perlakuan 10 ton $\mathrm{ha}^{-1}$ pupuk kotoran kambing pada umbi 6 minggu setelah simpan (MSS) menyebabkan persentase kerusakan bawang merah $1.4 \%$ yang nyata lebih tinggi dibandingkan dengan 0 ton $\mathrm{ha}^{-1}$ pupuk kotoran kambing (0.9\%) seperti tertera pada Tabel 8. Pengaruh pemberian pupuk kotoran kambing pada peningkatan kerusakan karena diduga berkaitan dengan pengaruh pada penurunan tingkat kekerasan umbi bawang merah. Hal tersebut dipengaruhi oleh kadar air yang tinggi di dalam umbi bawang merah sehingga respirasi meningkat sampai puncaknya hingga mencapai tahap pembusukan. Kerusakan bawang merah disebabkan proses kimiawi dan enzimatis yang dipicu oleh penurunan kadar air dalam bawang merah. Mutia et al. (2015) menyatakan, penurunan kadar air dalam bawang merah akan memicu proses mikrobiologis, kimiawi, dan enzimatis sehingga akan mempengaruhi laju kerusakan selama penyimpanan. Kekerasan umbi bawang merah juga dipengaruhi suhu ruang penyimpanan. Kasim et al. (2015) menyatakan, kadar air yang rendah dan umbi yang lebih keras ditemukan pada suhu tinggi dalam ruang penyimpanan umbi bawang merah pada dataran yang rendah. Selain itu, penelitian lain juga menambahkan bahwa penggunaan suhu yang tinggi pada penyimpanan bawang merah mempengaruhi laju transpirasi dari umbi dan daun bawang sehingga penguapan yang berlebihan berakibat pada susut bobot (Aziz et al., 2013). Perlakuan pupuk kotoran kambing terhadap kerusakan berbeda nyata namun persentase kerusakan tidak lebih 5\% sehingga hal tersebut sudah sesuai syarat mutu bawang merah.

\section{Serangan Hama}

Perlakuan pupuk kotoran kambing memberikan pengaruh nyata pada luas serangan hama Spodoptera exigua ketika umur tanaman 3 MST. Perlakuan 10 ton ha-1 pupuk kotoran kambing meningkatkan luas serangan dan intensitas keparahan S. exigua (Tabel 9). Hasil tersebut berbeda dengan penelitian sebelumnya Romdoni et al. (2019) 
Tabel 7. Pengaruh pupuk kotoran kambing dan pupuk anorganik terhadap kekerasan umbi bawang merah

\begin{tabular}{lccc}
\hline Dosis pupuk anorganik & $\begin{array}{c}\text { Tanpa pupuk organik } \\
\text { P0 (mm g detik) }\end{array}$ & $\begin{array}{c}\text { Pupuk organik } \\
\text { P1 (mm g detik) }\end{array}$ & $\begin{array}{c}\text { Rata-rata } \\
\text { P0+P1 }\end{array}$ \\
\hline A0 & 14.5 & 12.4 & 13.4 \\
A1 & 14.4 & 14.1 & 14.2 \\
A2 & 13.3 & 12.1 & 12.7 \\
A3 & 13.3 & 9.8 & 11.5 \\
A4 & 12.2 & 10.4 & 11.3 \\
\hline Rata-rata (Uji polynomial) & $13.5 \mathrm{a}$ & $11.7 \mathrm{~b}$ & $12.6(0.0004 * * \mathrm{~L})$ \\
\hline
\end{tabular}

Keterangan: $\mathrm{P} 0=0$ ton $\mathrm{ha}^{-1} ; \mathrm{P} 1=10$ ton ha ${ }^{-1} ; \mathrm{A} 0=0 \%$ dosis acuan; $\mathrm{A} 1=25 \%$ dosis acuan; $\mathrm{A} 2=50 \%$ dosis acuan; $\mathrm{A} 3=75 \%$ dosis acuan; $\mathrm{A} 4=100 \%$ dosis acuan; Uji orthogonal polynomial: $*$ = pengaruh nyata; $* *=$ pengaruh sangat nyata; $\mathrm{L}=$ linear; $\mathrm{K}=$ kuadratik

Tabel 8. Pengaruh pupuk kotoran kambing terhadap mutu umbi bawang merah

\begin{tabular}{lcc}
\hline Peubah mutu umbi & $\begin{array}{c}\text { Tanpa pupuk } \\
\text { organik } \\
\left(0 \text { ton ha }{ }^{-1}\right)\end{array}$ & $\begin{array}{c}\text { Pupuk organik } \\
\left(10 \text { ton } \mathrm{ha}^{-1}\right)\end{array}$ \\
\hline Kerusakan umbi $(\%)$ & $0.9 \mathrm{~b}$ & $1.4 \mathrm{a}$ \\
\hline
\end{tabular}

Keterangan: Angka yang diikuti oleh huruf yang sama pada kolom yang sama tidak berbeda nyata

Tabel 9. Pengaruh pupuk kotoran kambing terhadap luas serangan dan intensitas keparahan $S$. exigua pada 3 MST

\begin{tabular}{lcc}
\hline $\begin{array}{l}\text { Peubah serangan } \\
\text { hama }\end{array}$ & $\begin{array}{c}\text { Tanpa pupuk } \\
\text { organik } \\
\left(0 \text { ton } \mathrm{ha}^{-1}\right)\end{array}$ & $\begin{array}{c}\text { Pupuk organik } \\
\left(10 \text { ton } \mathrm{ha}^{-1}\right)\end{array}$ \\
\hline $\begin{array}{l}\text { Kejadian hama } S . \\
\text { exigua }(\%)\end{array}$ & $8.5 \mathrm{~b}$ & $37.0 \mathrm{a}$ \\
$\begin{array}{l}\text { Intensitas serangan } \\
\text { S. exigua }(\%)\end{array}$ & $7.4 \mathrm{~b}$ & $27.3 \mathrm{a}$ \\
\hline
\end{tabular}

Keterangan: Angka yang diikuti oleh huruf yang sama pada kolom yang sama tidak berbeda nyata. 0 ton $\mathrm{ha}^{-1}=\mathrm{P} 0 ; 10$ ton $\mathrm{ha}^{-1}=\mathrm{P} 1$

menyatakan perlakuan dosis acuan pupuk anorganik 50\% dan pemberian pupuk kotoran kambing mengurangi kejadian dan keparahan hama S. exigua pada 3 MST hingga $0 \%$. Hal ini berkorelasi dengan pengaruh pupuk kandang yang nyata meningkatkan total anakan dan total daun (Tabel 2 dan 3), serta daun bawang merah menjadi lebih hijau sehingga menjadi daya tarik bagi hama dan sangat rentan terhadap serangan hama, kondisi suhu rendah, kelembaban tinggi menyebabkan tingkat serangan hama tinggi. Surya et al. (2019) menyatakan kelembaban tanah dan udara merupakan faktor utama yang mempengaruhi serangan dan penyebaran hama pada bawang merah. Aplikasi pupuk anorganik yang terlalu tinggi disertai pemupukan pupuk organik diduga juga meningkatkan serangan hama di awal pertumbuhan, namun serangan hama ini masih dapat dikompensasi oleh jumlah daun yang lebih banyak pada perlakuan dengan pemberian pupuk organik kotoran kambing sehingga tidak sampai merusak umbi. Pemupukan yang berimbang dapat menyediakan unsur hara yang dibutuhkan oleh tanaman sehingga dapat tumbuh optimal dan mudah membentuk daun baru.

\section{KESIMPULAN}

Pupuk organik kotoran kambing dan pupuk anorganik, masing-masing nyata menurunkan tinggi tanaman, sebaliknya hanya pupuk organik kotoran kambing saja yang meningkatkan jumlah daun dan jumlah anakan. Pemberian pupuk organik kotoran kambing lebih banyak berpengaruh pada peubah produksi secara kuantitas seperti bobot umbi per rumpun dan per 100 rumpun. Pemberian pupuk organik kotoran kambing sebanyak 10 ton $\mathrm{ha}^{-1}$ berhasil nyata meningkatkan besaran produksi (32.79\%). Pupuk anorganik tidak berhasil meningkatkan produksi, bahkan menurunkan kualitas produksi, yakni persentase umbi besar dan kekerasan umbi. Penambahan pupuk organik kotoran kambing mengurangi peranan pupuk anorganik pada persentase umbi belah ketupat. Penambahan pupuk organik kotoran kambing pada umbi 6 minggu setelah simpan (MSS) menyebabkan persentase kerusakan bawang merah $1.40 \%$ tetapi masih di bawah 5\% menurut syarat mutu SNI 01-3159-1992 bawang merah.

\section{DAFTAR PUSTAKA}

Abreu, AC., A.J. McBain, M. Simoes. 2012. Plants as sources of new antimicrobials and resistance-modifying agents. Nat. Prod. Rep. 29:1007-1021.

Ali, M., N. Khan, A. Khan, R. Ullah, A. Naeem, M.W. Khan, K Khan, S Farooq, K Rauf. 2018. Organic manures effect on the bulb production of onion cultivars under semiarid condition. Pure Appl Biol. 7:1161-1170. 
Aziz, A., Ete A, Bahrudin. 2013. Karakterisasi sumber benih bawang merah dari berbagai daerah sentra produksi di lembah Palu. J. Agrotekbis 9:221-227.

Badan Pusat Statistik. 2018. Jumlah penduduk Indonesia. https://www.bps.go.id. [9 Juli 2019].

Badan Pusat Statistik. 2018. Produksi bawang merah 2017. https:/www.bps.go.id/site/resultTab. [22 Juli 2018].

Dhaker, B., R.K. Sharma, B.G. Chhipa, R.S Rathore. 2017. Effect of different organic manures on yield and quality of onion [Allium cepa (L.)]. Int. J. Curr. Microbial. App. Sci. 6:3412-3417.

Downes, K.,A. Gemma, Chope, L.A. Terry. 2010. Postharvest application of ethylene and 1-methylcyclopropene either before or after curing affects onion [Allium cepa (L.)] bulb quality during long term cold storage. Postharvest Biology and Technology 55:36-44.

Hu, T., P. Sorensen, J.E. Olesen. 2018. Soil carbon varies between different organic and conventional management schemes in arable agriculture. Eur. J. Agronomy 94:79-88.

Ibrahim, M.H., H.Z.E. Jaafar, E. Karimi, A. Ghasemzadeh. 2013. Impact of organic and inorganic fertilizers application on the phytochemical and antioxidant activity of kacip fatimah [Labisia pumila Benth]. Molecules 18:10973-10988.

Kasim, M., Bahrudin, Y. Tambing. 2015. Pengaruh berbagai dosis pupuk $\mathrm{KCl}$ dan ketinggian tempat penyimpanan terhadap kualitas benih bawang merah varietas lembah palu. e-J. Agrotekbis. 3:630-637.

Lawenga, F.F., H. Uswah, W. Danang. 2015. Pengaruh pemberian pupuk organik terhadap sifat fisika tanah dan hasil tanaman tomat (Lycopersicum esculentum Mill.) di Desa Bulupountu Kecamatan Sigi Biromaru Kabupaten Sigi. e-J. Agrotekbis. 3:564-570.

Messele, B. 2016. Effects of nitrogen and phosphorus rates on growth, yield, and quality of onion [Allium cepa (L.)] at menschen fur menschen demonstration site, Harar, Ethiopia. J. Agric. Res. Tech. 1:555-563.

Mukhlis, Sariffudin, H. Hanum. 2011. Kimia Tanah Teori dan Aplikasi. Universitas Sumatera Utara Press, Medan, ID.

Mutia, A.K., Y.A. Purwanto, L. Pujantoro. 2014. Perubahan kualitas bawang merah [Allium ascalonicum (L.)] Selama penyimpanan pada tingkat kadar air dan suhu yang berbeda. J. Pascapanen 11:108-115.
Rashid, M. 2016. Impact of nitrogen, phosporus and potassium on brown planthopper and tolerance of its host rice plants. Rice Sci. 23:119-131.

Ren, F., K. Reilly, J.P. Kerry, M. Gaffney, M. Hossain, D.K. Rai. 2017. Higher antioxidant activity, total flavonols, and specific quercetin glucosides in two different onion [Allium cepa (L.)] varieties grown under organic production: results from a 6-year field study. J. Agric. Food Chem. 65:5122-5132.

Romdoni, A., Suwarto, M. Awang, S.Y Titiek. 2019. Pengaruh penggantian pupuk anorganik dengan pupuk kandang terhadap pertumbuhan produksi dan daya simpan pada umbi bawang merah. J.Agron. Indonesia 47:283-290.

Surat Keputusan Kementerian Pertanian RI No.66/Kpts/ TP.240/2.2000. Pelepasan varietas bawang merah "Philipine" sebagai varietas unggul dengan nama Super Philip. Buletin Ikatan Vol. 3 No. 2 Tahun 2013 7.

Surat Keputusan Kementerian Pertanian RI No.66/Kpts/ TP.240/2.2000. Pelepasan varietas bawang merah "Philipine" sebagai varietas unggul dengan nama Super Philip. Buletin Ikatan Vol. 3 No. 2 Tahun 2013 7.

Sumarni, N., R. Rosliani, R.S. Basuki. 2012. Respon Pertumbuhan hasil umbi dan serapan hara NPK tanaman bawang merah terhadap berbagai dosis pemupukan NPK pada tanah alluvial. J. Hort. 22:366375.

Surya E, Armi, Ridhwan M, Syahrizal H. 2019. Kerusakan tanaman bawang merah (Allium ascalonicum L.) akibat serangan hama ulat tanah (Agrotis ipsilon) di lahan bawang merah gampong lam rukam kecamatan peukan bada Kabupaten Aceh Besar. Bio J. 6: 88-99.

Susanti, A.A., B. Waryanto. 2017. Outlook Tanaman Pangan Dan Hortikultura. Direktorat Jendral Pertanian, Jakarta, ID.

Thangasamy, A., K. Gorrepati, T.P.S Ahammed, R.K. Savalekar, K. Banerjee, V. Sankar, M.K Chavan. 2017. Comparison of organic and conventional farming for onion yield, biochemical quality, soil organic carbon, and microbial population. Archives Agron. Soil Sci. 2017:219-230.

Yohannes, K.W., D. Belew, A. Debela. 2013. Effect of farmyard manure and nitrogen fertilizer rates on growth, yield and yield component of onion [Allium cepa (L.)] at Jimma, Southwest Ethiopia. Asian J. Plant Sci. 12:228-234. 